\title{
Flow cytometric detection of cell-associated cytokines in alveolar macrophages
}

\author{
H. Nakamura, S. Fujishima, K. Soejima, Y. Waki, M. Nakamura, \\ A. Ishizaka, M. Kanazawa
}

Flow cytometric detection of cell-associated cytokines in alveolar macrophages. $H$. Nakamura, S. Fujishima, K. Soejima, Y. Waki, M. Nakamura, A. Ishizaka, M. Kanazawa. (c)ERS Journals Ltd 1996.

ABSTRACT: To elucidate the cytokine-producing capacity of alveolar macrophages (AMs), we have introduced a method of flow cytometry combined with saponin treatment to detect the cell-associated cytokines.

We studied bronchoalveolar lavage fluid cells from six patients with sarcoidosis (SAR) and six control (CTL) subjects. Cells were either left uncultured, or cultured with and without lipopolysaccharide (LPS), then treated with paraformaldehyde and saponin and analysed for cell-associated interleukin-1 $\beta$ (IL-1 $\beta$ ) and tumour necrosis factor- $\alpha($ TNF- $\alpha)$ by flow cytometry. Cell-associated IL-1 $\beta$ and TNF- $\alpha$ were also analysed by immunoassays.

The flow cytometric cytokine values were correlated with the immunoreactive cell-associated cytokines (IL-1 $\beta$ : $r=0.45, p<0.05$; TNF- $\alpha: r=0.82, p<0.001$ ). The histograms of cell-associated IL-1 $\beta$ yielded a single peak both in the patients and controls, whereas the histograms of cell-associated TNF- $\alpha$ exhibited two peaks in SAR patients, but just a single peak in the CTL subjects. The mean value of the cellassociated TNF- $\alpha$ in LPS(+) AMs was higher in the SAR patients than in the CTL subjects $(\mathbf{p}<0.001)$.

In conclusion, the flow cytometric method can be applied to the semiquantitative detection of cell-associated cytokines in alveolar macrophages at the single cell level. Eur Respir J., 1996, 9, 1181-1187.

It has been suggested that alveolar macrophages (AMs) contribute to the pathogenesis of inflammatory lung diseases by producing large quantities of proinflammatory cytokines, including interleukin-1 (IL-1) and tumour necrosis factor (TNF) in the alveolar spaces [1-3]. Bronchoalveolar lavage (BAL) has enabled us to obtain AMs from patients with various lung diseases, and numerous researchers have focused on the role of AMs in the pathophysiology of interstitial lung diseases, such as sarcoidosis (SAR) and idiopathic pulmonary fibrosis [2-5]. BAL fluid supernatant obtained from such patients has been used to measure the concentrations and biological activity of cytokines $[6,7]$.

However, the cytokine-producing cells remain unidentified despite the elevated cytokine levels in BAL fluid supernatants. Analysis of AM cytokine messenger ribonucleic acid (mRNAs) is a well-established approach to elucidating the involvement of cytokines [5, 7]. Nonetheless, AM separating procedures themselves may induce cytokine mRNA expression, as certain cytokines are induced in AMs by adhesion to culture dishes [8]. In addition, the degree of cytokine mRNA expression is not always correlated with the amount of cytokine protein production [9].

The flow cytometric method, using saponin treatment, has recently been reported to be applicable to the detection of cell-associated cytokines in peripheral blood monocytes and lymphocytes [10-12]. This method has never been applied to the analysis of cell-associated cytokines in AM. We have, therefore, attempted to establish a flow cytometric method for the detection of cell-associated cytokines in AMs. The significance and merits of this procedure are discussed.

\section{Patients and methods}

\section{Study population}

The study subjects consisted of six SAR patients and six control (CTL) subjects. SAR was diagnosed on the basis of a chest radiograph, characteristics of BAL cell differential counts and histological findings. Transbronchial lung biopsy revealed noncaseating granulomas in all six SAR patients. The average age of these SAR patients ( 4 males and 2 females) was $31 \pm 3$ yrs, less than that of the CTL subjects $(p<0.01)$. Four were current smokers and two had never smoked. Four patients showed bilateral hilar lymphadenopathy (BHL) alone on chest radiography and two showed BHL with lung field nodular densities. The CTL group was comprised of the following subjects: 1) two patients with a recent history of haemoptysis, but no abnormal findings on chest radiography or bronchoscopy; and 2) four patients with a small solitary coin lesion less than $2 \mathrm{~cm}$ in diameter (three with scar tissue, one with early lung cancer). BAL was performed on the 
opposite lung in the latter four patients. The average age of the six CTL subjects (5 males and 1 female) was $49 \pm 3$ yrs. Five were current smokers and the other patient had never smoked. All study subjects gave their informed consent before the procedure.

\section{$B A L$ procedure}

BAL was performed in all subjects using a standard protocol, as described previously [13]. Briefly, a bronchoscope was wedged in a segment of the right middle lobe or lingula. Sterile normal saline was instilled through the bronchoscope in $50 \mathrm{~mL}$ aliquots to a total of $150 \mathrm{~mL}$. The recovered BAL fluid was filtered through sterile gauze and the number of cells was counted. Cytospin preparations were made for cell differential counts. The fluid was centrifuged at $200 \times \mathrm{g}$ for $5 \mathrm{~min}$ and the cells were collected.

\section{Discrimination between AMs and lymphocytes on a two-} dimensional forward and side scattergram

BAL fluid cells from three SAR patients were studied. The cells were incubated with $100 \mu \mathrm{g}$ of aggregated immunoglobulin $\mathrm{G}(\mathrm{IgG})$ (Human $\gamma$-Globulin Cohn Fraction II, III; Sigma Chemical Co., St. Louis, MO, USA) for $10 \mathrm{~min}$ at $4^{\circ} \mathrm{C}$. The cells were then incubated with either $1 \mu \mathrm{g}$ of fluorescein isothiocyanate (FITC)-conjugated control IgG (Becton-Dickinson Lab., Lincoln Park, NJ, USA) or anti-CD3 antibody (Becton-Dickinson) for 30 min at $4^{\circ} \mathrm{C}$, washed with phosphate-buffered saline (PBS), and suspended in PBS containing $1 \%$ paraformaldehyde (PFA). Cell populations were gated on a two-dimensional forward and side scattergram, and the fluorescence intensity of each cell population was measured with a flow cytometer (FACScan; Becton-Dickinson).

\section{Cell culture conditions}

BAL fluid cells from all study subjects were suspended in $15 \mathrm{~mL}$ of the culture medium: RPMI-1640 (IBL, Gunma, Japan) supplemented with 10\% low endotoxin foetal calf serum (Gibco BRL, Grand Island, NY, USA), $10 \mathrm{mM}$ hydroxyethylpiperazine ethanesulphonic acid (HEPES) buffer, $100 \mathrm{U} \cdot \mathrm{mL}^{-1}$ penicillin, $100 \mathrm{ng} \cdot \mathrm{mL}^{-1}$ streptomycin. The cells were divided into three groups: an uncultured group kept for $4 \mathrm{~h}$ at $4{ }^{\circ} \mathrm{C}$; an LPS(-) group cultured for $4 \mathrm{~h}$ at $37^{\circ} \mathrm{C}$ on $10 \mathrm{~cm}$ culture dishes (BectonDickinson), and a LPS(+) group cultured with $1 \mu \mathrm{g} \cdot \mathrm{mL}^{-1}$ of LPS (Escherichia coli 055: B5, Difco, Detroit, MI, USA) for $4 \mathrm{~h}$ at $37^{\circ} \mathrm{C}$ on $10 \mathrm{~cm}$ culture dishes. In certain experiments, brefeldin A (Gibco BR) was added to the culture medium.

Flow cytometry detection of intracellular vimentin and cell-associated cytokines in AMs

Intracellular vimentin [14] was detected in AMs from the six CTL subjects and cell-associated IL- $1 \beta$ and TNF$\alpha$ in AMs from all study subjects using the flow cytometric method. After culture, the cells were fixed with PBS containing $1 \%$ PFA for $1 \mathrm{~h}$ at $4{ }^{\circ} \mathrm{C}$ and then incubated with PBS containing $0.1 \%$ saponin (Wako Junyaku
Co., Osaka, Japan) for $1 \mathrm{~h}$ at $37^{\circ} \mathrm{C}$ to allow antibodies to penetrate the cell membrane [12]. The cells were then incubated with $1 \mu \mathrm{g} \cdot 10 \mu \mathrm{L}^{-1}$ of either class-matched control IgG (Becton-Dickinson), anti-vimentin (Signet Laboratories Inc., Dedham, MA, USA), anti-IL-1 $\beta$ (Becton-Dickinson) or anti-TNF- $\alpha$ (Genentech Inc., S. San Francisco, CA, USA) monoclonal antibody for $30 \mathrm{~min}$ at $4^{\circ} \mathrm{C}$. In one set of experiments, $1 \mu \mathrm{g} \cdot 10 \mu \mathrm{L}^{-1}$ anti-IL- $1 \beta$ or anti-TNF- $\alpha$ antibody was preincubated with $0.1 \mu \mathrm{g} \cdot 10 \mu \mathrm{L}^{-1}$ and 1 $\mu \mathrm{g} \cdot 10 \mu \mathrm{L}^{-1}$ or TNF- $\alpha$ overnight at $4^{\circ} \mathrm{C}$ to neutralize the antibody. The cells were incubated with secondary FITCconjugated goat anti-mouse $\operatorname{IgG} \mathrm{F}\left(\mathrm{ab}^{\prime}\right)_{2}$ (Tago Inc., Burlingame, CA, USA) for $30 \mathrm{~min}$ at $4^{\circ} \mathrm{C}$, washed with PBS containing $0.1 \%$ saponin, and suspended in PBS containing 1\% PFA. AMs were gated on the two-dimensional forward and side scattergram of the flow cytometer and fluorescence intensity was analysed. The percentage of positive cells was also determined using class-matched $\mathrm{IgG}$ as a control. The mean fluorescence intensity of AMs for anti-vimentin, IL-1 $\beta$ or TNF- $\alpha$ antibody was divided by that of the AMs for control IgG to calculate relative fluorescence intensity in this study.

Detection of cell-associated cytokines using immunoassays

Cell-associated IL-1 $\beta$ and TNF- $\alpha$ were measured in AMs from three SAR patients and six CTL subjects by radioimmunoassay (RIA) and enzyme-linked immunosorbent assay (ELISA). After culture, the BAL cells were suspended in $3 \mathrm{~mL}$ of RPMI-1640, frozen at $-70^{\circ} \mathrm{C}$ for $1 \mathrm{~h}$, and then thawed at $37^{\circ} \mathrm{C}$ for $1 \mathrm{~h}$. This procedure was repeated three times, and cell-associated cytokines were extracted [15]. IL-1 $\beta$ concentrations in the supernatants were measured by RIA (Amersham, Buckinghamshire, UK) and TNF- $\alpha$ by ELISA (Otsuka Pharmaceutical Co., Tokushima, Japan). The values of cell-associated IL-1 $\beta$ and TNF- $\alpha$ in $10^{5}$ AMs were calculated and compared with the relative fluorescence intensities obtained by flow cytometry.

\section{Statistical analysis}

All data shown are mean \pm SEM. Paired and unpaired Student's t-tests were used to compare mean values. Significance was accepted at a p-value of less than 0.05 .

\section{Results}

\section{BAL fluid cell analysis}

In the CTL subjects, the total BAL cell count was $3.5 \pm 1.0 \times 10^{5}$ cells $\cdot \mathrm{mL}^{-1}$ and the BAL cell differentials were as follows: AMs, $91.3 \pm 2.0 \%$; lymphocytes $7.2 \pm 1.6 \%$; and neutrophils $1.5 \pm 0.7 \%$. In the SAR patients, the total cell count was $6.3 \pm 1.3 \times 10^{5}$ cells $\cdot \mathrm{mL}^{-1}$, and the cell differentials were as follows: AMs $58.8 \pm 8.0 \%$; lymphocytes $40.6 \pm 8.3 \%$; and neutrophils $0.6 \pm 0.4 \%$. The percentage of AMs in SAR was lower than in the CTL subjects $(p<0.01)$, but the percentage of lymphocytes was higher 


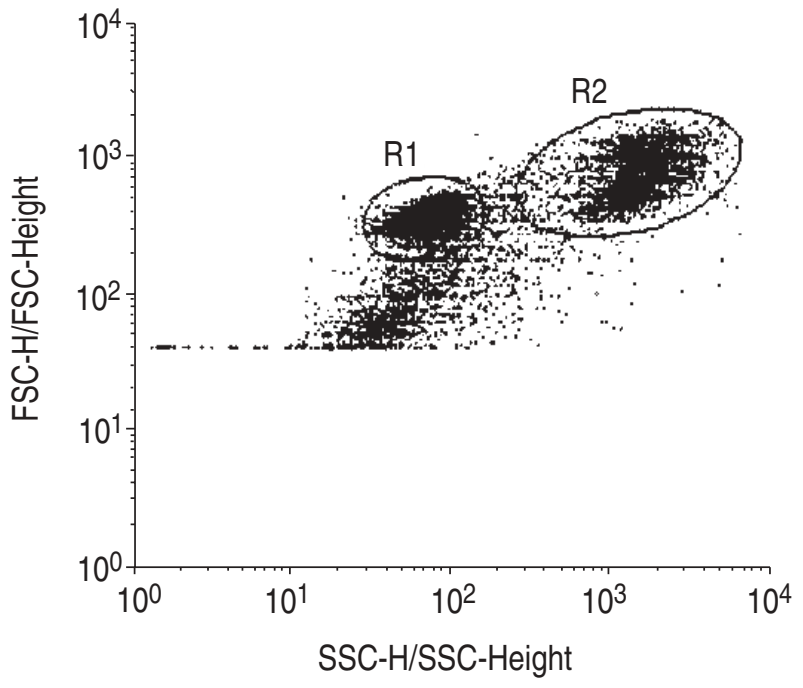

Fig. 1. - A two-dimensional forward (FSC) and side (SSC) scattergram obtained from a patient with sarcoidosis. The $\mathrm{x}$-axis shows the side scatter by log scale, and the $y$-axis shows the forward scatter by $\log$ scale. The cell population with smaller forward and side scatters was gated as R1. The other cell population with larger scatters was gated as R2

than in the CTL subjects $(\mathrm{p}<0.01)$. The mean CD4/CD8 ratio in SAR was 5.5 \pm 1.2 .

Discrimination between AMs and lymphocytes on a twodimensional forward and side scattergram

As shown in figure 1, BAL fluid cells from SAR patients were separated into two cell populations on a two-dimensional forward and side scattergram. The cell population with smaller forward and side scatters was gated as R1. The other cell population with larger scatters was gated as $\mathrm{R} 2$. The percentage of $\mathrm{CD} 3$ cells in the $\mathrm{R} 1$ of the three SAR patients was $86.3 \pm 1.2 \%$ versus $4.5 \pm 0.6 \%$ in the $R 2$, confirming that most R2 cells are AMs.

Detection of intracellular vimentin in AMs by flow cytometry

The relative fluorescence intensities of vimentin in the uncultured, LPS(-) and LPS(+) AMs were 5.8 $\pm 1.8,7.3 \pm 1.4$ and $6.6 \pm 1.3$, respectively, in the six CTL subjects. There were no significant differences in these values among the three culture conditions.

\section{Histograms of cell-associated cytokines in AMs}

Figures 2 and 3 show the histograms of LPS(+) AMs from a CTL subject and a SAR patient. In the CTL subjects, the histograms of control IgG, IL- $1 \beta$ and TNF- $\alpha$ all possessed single-peak fluorescence intensity (fig. 2). In the SAR patients, the histograms of the control and IL- $1 \beta$ showed single peak, whilst the histogram of TNF- $\alpha$ yielded two peaks (fig. 3).

To confirm that we had detected cell-associated IL-1 $\beta$ and TNF- $\alpha$ with the cytokine-specific antibodies, and not nonspecific interactions with AMs, we examined the effect of neutralizing the antibodies with IL- $1 \beta$ and TNF- $\alpha$ on the histograms of LPS(+) AMs. Preincubation of anti-IL-1 $\beta$ a)
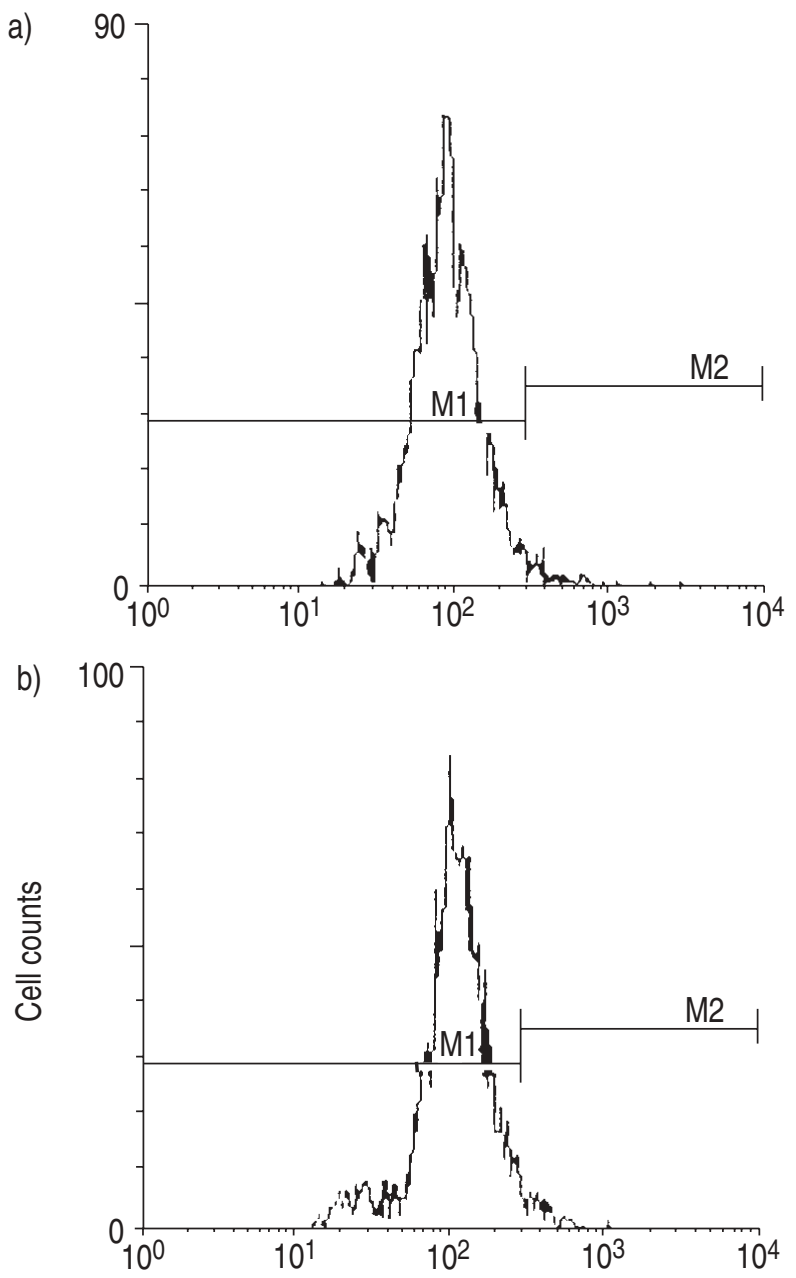

c)

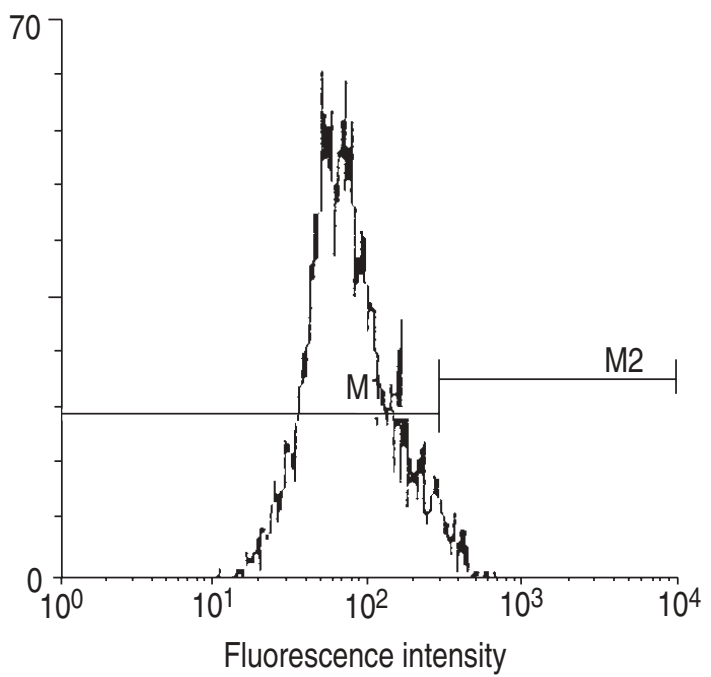

Fig. 2. - Histograms of LPS(+) AMs from a CTL subject. The $\mathrm{x}$-axis show fluorescence intensity by $\log$ scale, and the y-axis shows cell counts on a linear scale. a) Control; b) IL- $1 \beta$; c) TNF- $\alpha$. The histograms of the control IgG, IL- $1 \beta$ and TNF- $\alpha$ all have single peaks. The same findings were observed in the other CTL subjects. LPS: lipopolysaccharide; AMs: alveolar macrophages; CTL: control; IgG: immunoglobulin G; IL-1 $\beta$ : interleukin-1 $\beta$; TNF- $\alpha$ : tumour necrosis factor- $\alpha$.

antibody with IL-1 $\beta$ abrogated the increase in mean fluorescence (fig. 4a). Similarly, neutralization of anti-TNF- $\alpha$ antibody with TNF- $\alpha$ abolished the increase in mean fluorescence intensity (fig. $4 b$ ). 

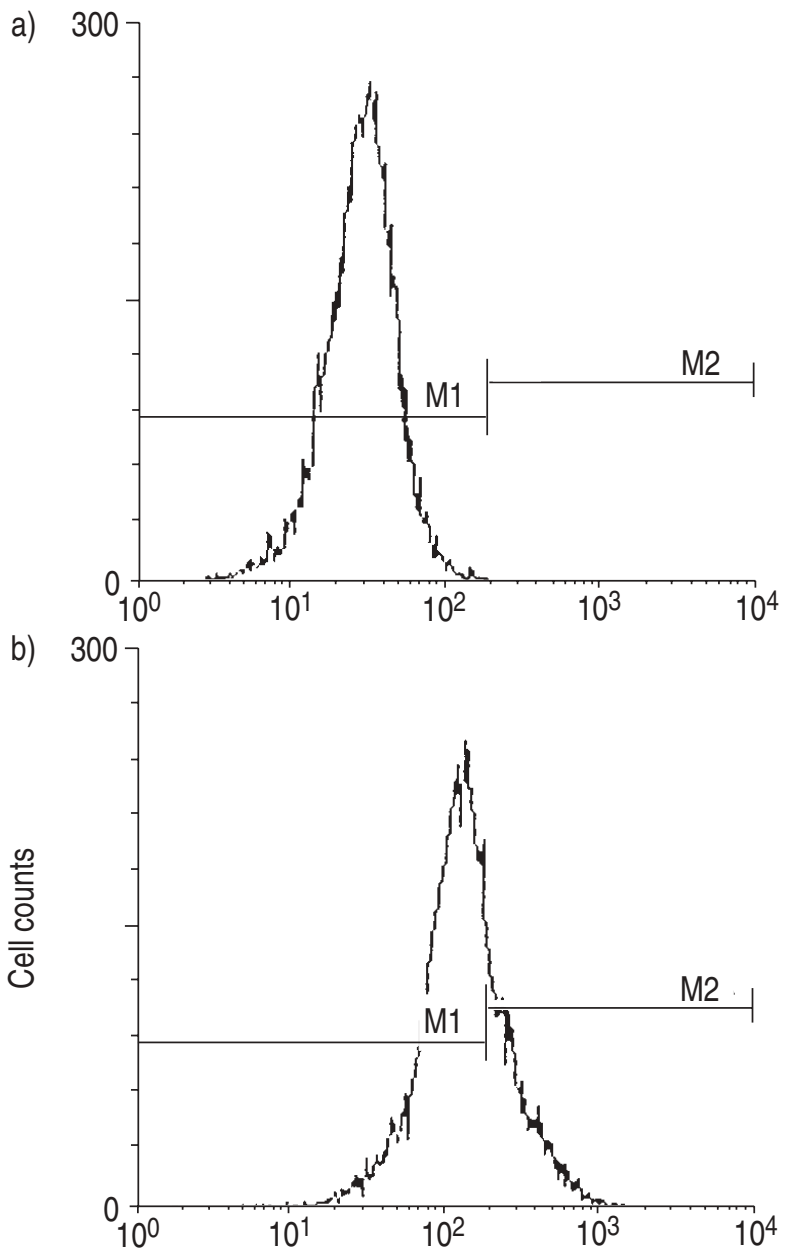

c) 160

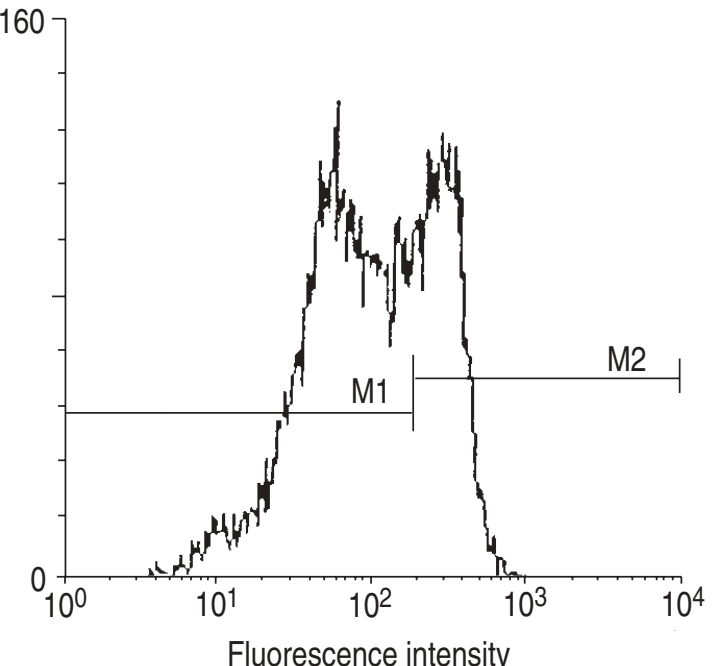

Fig. 3. - Histograms of LPS(+) AMs from a SAR patient. The xaxis shows fluorescence intensity by $\log$ scale, and the $y$-axis shows cell counts on a linear scale. a) Control; b) IL- $1 \beta$; c) TNF- $\alpha$. The histograms of the control IgG and IL- $1 \beta$ possess single peaks, but the histogram of TNF- $\alpha$ is composed of two peaks. Similar results were obtained for the other SAR patients. SAR: sarcoidosis. For further definitions see legend to figure 2 .

Cell-associated IL-1 $\beta$ and TNF- $\alpha$ measured by flow cytometry in AMs from CTL subjects

As shown in figure 5a, the relative fluorescence intensity of IL-1 $\beta$ in the LPS(+) group was higher than in the a)

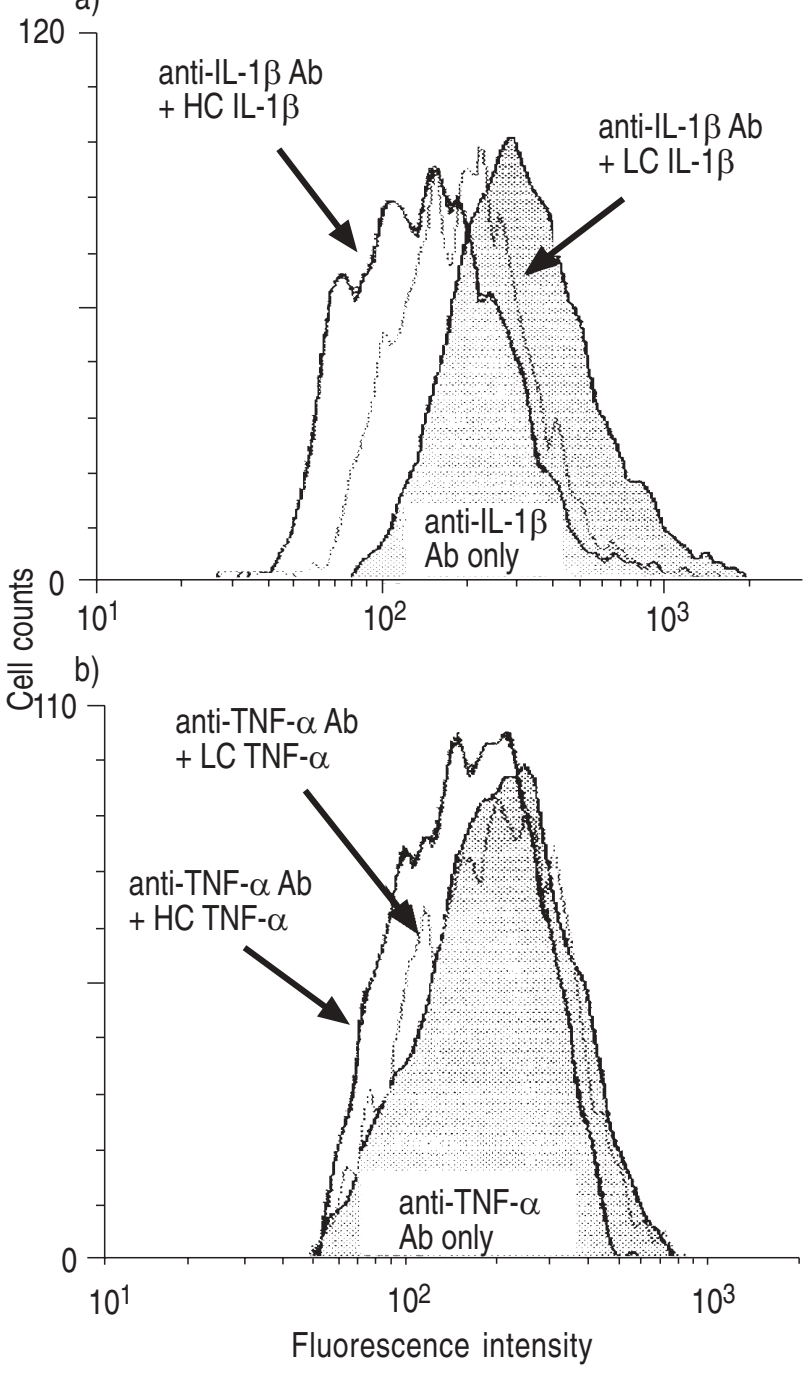

Fig. 4. - Effect of neutralization of anti-IL-1 $\beta$ and anti-TNF- $\alpha$ antibodies with IL- $1 \beta$ and TNF- $\alpha$, respectively. a) Neutralization of $1 \mu \mathrm{g} \cdot 10$ $\mu L^{-1}$ anti-IL-1 $\beta$ antibody with two different concentrations of IL-1 $\beta$ (LC: $0.1 \mu \mathrm{g} \cdot 10 \mu \mathrm{L}^{-1}$; HC: $1 \mu \mathrm{g} \cdot 10 \mu \mathrm{L}^{-1}$ ). Shaded area represents the effect of anti-TNF- $\alpha$ Ab alone Pretreatment with IL-1 $\beta$ shifted the histogram to the left dose dependently. b) Neutralization of $1 \mu \mathrm{g} \cdot 10$ $\mu \mathrm{L}^{-1}$ anti-TNF- $\alpha$ antibody with two different concentrations of TNF$\alpha$ (LC: $0.1 \mu \mathrm{g} \cdot 10 \mu \mathrm{L}^{-1}$; HC: $1 \mu \mathrm{g} \cdot 10 \mu \mathrm{L}^{-1}$ ). Shaded area represents the effect of anti-TNF- $\alpha$ Ab alone. Pretreatment with TNF- $\alpha$ shifted the histogram to the left dose-dependently. LC: low concentration; HC: high concentration; $\mathrm{Ab}$ : antibody. For further definitions see legend to figure 2 .

uncultured group $(\mathrm{p}<0.05)$. The relative fluorescence intensity of TNF- $\alpha$ was higher both in the LPS $(+)$ and the LPS(-) groups than in the uncultured group $(\mathrm{p}<0.001$ and $\mathrm{p}<0.05$, respectively), and also higher in the $\operatorname{LPS}(+)$ group than in the LPS $(-)$ group $(\mathrm{p}<0.001)$.

Since the changes in relative fluorescence intensity were small, especially for IL-1 $\beta$, we tried using brefeldin A, an agent which blocks the secretion of various proteins, to increase the sensitivity of the flow cytometric method [16]. Co-incubation with brefeldin A increased the mean fluorescence intensity of TNF- $\alpha$ (1.04 without brefeldin A $v s$ 1.52 with, $n=2)$, but rather decrease that of IL-1 $\alpha$ (1.47 without brefeldin A vs 1.21 with; $n=2$ ). Since the change in the cell-associated TNF- $\alpha$ was detectable without brefel$\operatorname{din} \mathrm{A}$, it was not used in this experiment. 

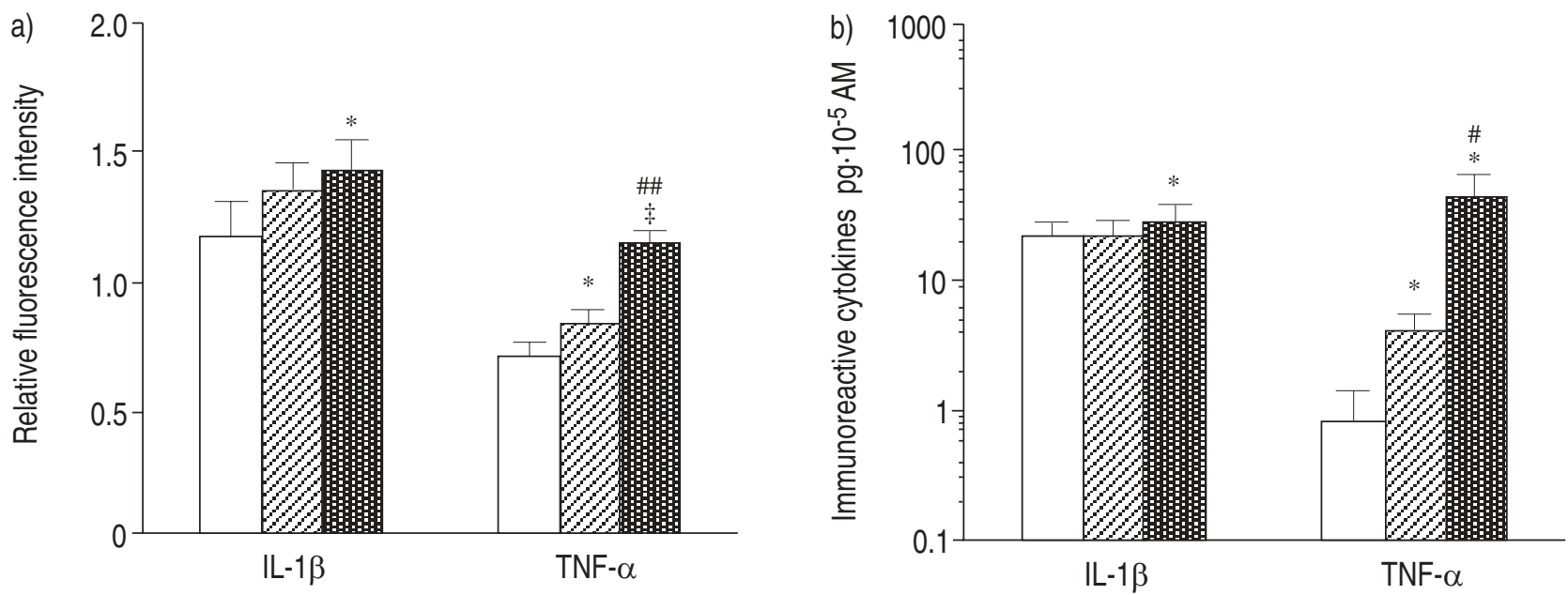

Fig. 5. - Cell associated cytokines in AMs from CTL subjects. a) Results by the flow cytometric method. Relative fluorescence intensity of IL$1 \beta$ was higher in the LPS $(+)$ group than in the uncultured group $(*: \mathrm{p}<0.05)$. That of TNF- $\alpha$ was higher both in the LPS $(+)$ and the LPS $(-)$ groups than in the uncultured group (†: $\mathrm{p}<0.001$ and $*: \mathrm{p}<0.05$, respectively). It was also higher in the LPS $(+)$ group than in the LPS(-) group (\#\#: $\mathrm{p}<0.001)$. b) results obtained with the immunoassays. The IL-1 $\beta$ concentration was higher in the LPS(+) group than in the uncultured group (*: $\mathrm{p}<0.05)$. The TNF- $\alpha$ concentration was higher in both the LPS $(+)$ and LPS(-) group than in the uncultured group (*: p $<0.05$ for both). It was also higher in the

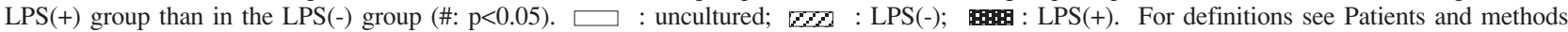
section.

Cell-associated IL-1 $\beta$ and TNF- $\alpha$ measured by immunoassay in AMs from CTL subjects

RIA and ELISA were also used to quantify the cellassociated IL-1 $\beta$ and TNF- $\alpha$ extracted from uncultured, LPS(-) and LPS(+) BAL cells. As shown in figure $5 b$, the IL-1 $\beta$ concentration was higher in the LPS $(+)$ group than in the uncultured group $(\mathrm{p}<0.05)$. The TNF- $\alpha$ concentration was higher both in the LPS(+) and the LPS(-) groups than in the uncultured group (both $\mathrm{p}<0.05$ ). It was also higher in the LPS(+) group than in the LPS(-) group $(\mathrm{p}<0.05)$. These results were consistent with those of the flow cytometric analysis.

a)

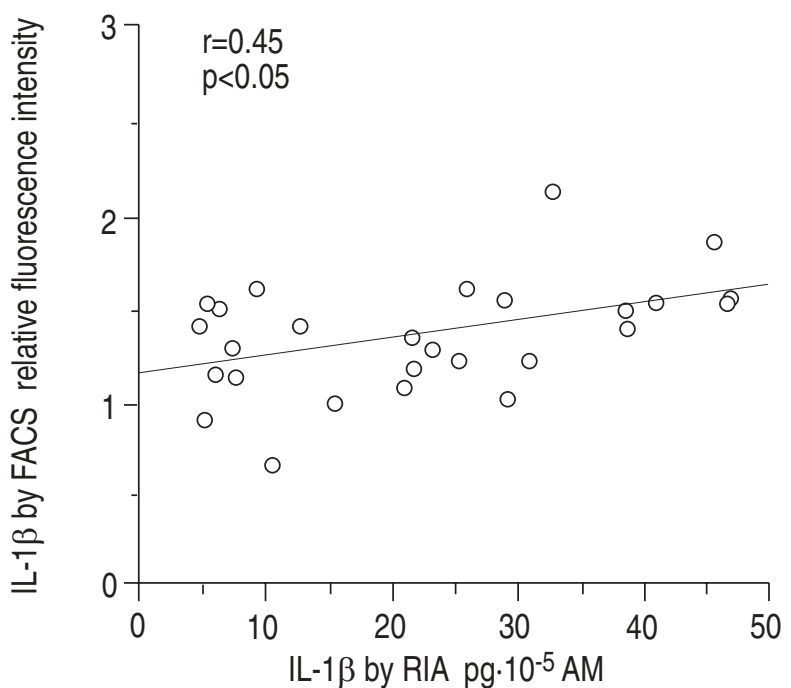

Comparison of cytokine values obtained by flow cytometry and immunoassay

Cell-associated IL-1 $\beta$ and TNF- $\alpha$ in AMs from the six CTL subjects and the three SAR patients were measured by both flow cytometry and immunoassay. Three AM specimens, i.e. the uncultured, LPS(-) and LPS(+) groups were measured by both methods in each patient, and a total 27 specimens were examined. The correlation between the two IL-1 $\beta$ values is shown in figure $6 \mathrm{a}$. There was a significant correlation between the values obtained by the two different methods $(\mathrm{r}=0.45 ; \mathrm{p}<0.05)$. The correlation between the TNF- $\alpha$ values is shown in

b)

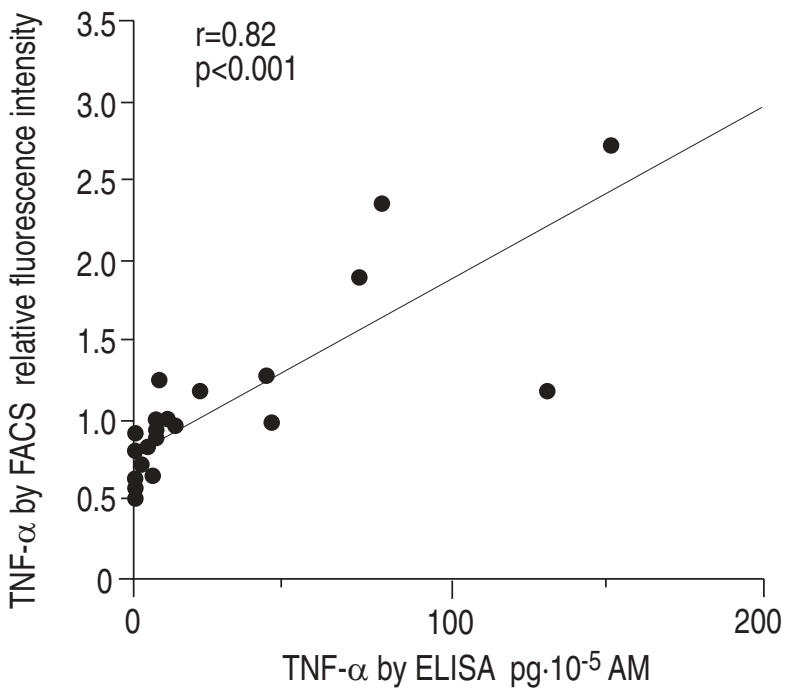

Fig. 6. - Comparison of the cytokine values determined by flow cytometry and immunoassay. a) Correlation between IL-1 $\beta$ values obtained by the two methods. There was a significant correlation between values $(r=0.45 ; \mathrm{p}<0.05)$. b) Correlation between TNF- $\alpha$ values obtained by the two methods. Again, there was a significant correlation ( $\mathrm{r}=0.82 ; \mathrm{p}<0.001)$. RIA: radioimmunoassay; ELISA: enzyme-linked immunosorbant assay; FACS: fluorescence-activated cell sorter. For further definitions see legend to figure 2. 
Table 1. - Relative fluorescence intensities of AMs of CTL subjects and SAR patients according to the results of flow cytometry

\begin{tabular}{lccccccc}
\hline & \multicolumn{3}{c}{ IL-1 $\beta$ (relative fluorescence intensity) } & & \multicolumn{3}{c}{ TNF- $\alpha$ (relative florescence intensity) } \\
\cline { 2 - 3 } Group & Uncultured & LPS(-) & LPS $(+)$ & & Uncultured & LPS(-) & LPS $(+)$ \\
\hline CTL $(\mathrm{n}=6)$ & $1.17 \pm 0.14$ & $1.34 \pm 0.09$ & $1.42 \pm 0.12$ & & $0.70 \pm 0.06$ & $0.83 \pm 0.06$ & $1.14 \pm 0.05$ \\
SAR $(\mathrm{n}=6)$ & $1.20 \pm 0.17$ & $1.41 \pm 0.28$ & $1.68 \pm 0.25$ & & $0.64 \pm 0.08$ & $0.82 \pm 0.08$ & $2.12 \pm 0.19$ \\
\hline
\end{tabular}

Values are presented as mean \pm SEM. $\div$ : $<0.001$, as compared with CTL. AMs: alveolar macrophages; CTL: control; SAR: sarcoidosis; LPS: lipopolysaccharide.

figure 6b. Again, there was a significant correlation between the values obtained by the two methods $(\mathrm{r}=0.82$; $\mathrm{p}<0.001)$.

Comparison of flow cytometry cytokine values of the CTL subjects and SAR patients

As shown in table 1 , there were no significant differences between the cell-associated IL- $1 \beta$ values of the uncultured, LPS(-) and LPS(+) groups in CTL subjects and SAR patients. In contrast, the cell-associated TNF- $\alpha$ level in the LPS(+) group in the SAR patients was significantly higher than in the CTL subjects $(p<0.001)$, although no difference was detected in cell-associated TNF- $\alpha$ in the uncultured and the LPS(-) groups between CTL subjects and SAR patients. Since SAR patients showed two peaks on the TNF- $\alpha$ histogram, the two peaks were analysed independently (table 2 ). Both peaks consisted of equal numbers of AMs, indicating the existence of heterogeneous AMs having different TNF- $\alpha$ producing capacity.

The percentage of positive cells in each group of CTL subjects and SAR patients was also examined (table 3 ). Cell-associated TNF- $\alpha$ in AMs was also significantly higher in the SAR patients than in the CTL subjects according to this parameter.

Table 2. - Relative fluorescence intensities for TNF- $\alpha$ of LPS-stimulated AM subpopulations in SAR patients according to the results of flow cytometry

\begin{tabular}{ccc}
\hline Subpopulations & $\begin{array}{c}\text { Cells included in } \\
\text { the subpopulations } \\
\%\end{array}$ & $\begin{array}{c}\text { Relative } \\
\text { fluorescence } \\
\text { intensities }\end{array}$ \\
\hline M1 & $56.3 \pm 2.4$ & $1.11 \pm 0.12$ \\
M2 & $43.7 \pm 2.4$ & $4.26 \pm 0.82$ \\
\hline
\end{tabular}

Values are presented as mean \pm SEM. $¥: \mathrm{p}<0.001$, as compared with M1 (paired t-test). TNF- $\alpha$ : tumour necrosis factor- $\alpha$. For further definitions see legend to table 1 .

\section{Discussion}

In the present study, we analysed cell-associated IL$1 \beta$ and TNF- $\alpha$ in AMs by a novel flow cytometric method and found that the AMs of SAR patients have a greater capacity to produce cell-associated TNF- $\alpha$ in response to LPS stimulation. This procedure enables us to measure cell-associated cytokines in AMs semiquantitatively without cell-separating procedures, which may activate AMs thereby inducing cytokine production [8]. Thus, we believe that this procedure will provide a new method of investigating cytokine production by AMs in various inflammatory lung diseases.

AMs were distinguished from lymphocytes (mostly Tcells) on a two-dimensional forward and side scattergram based on the proportion of CD3 cells in the SAR patients. Vimentin, a cell matrix protein [14], was detected in AMs, indicating that intracellular antigens can be detected by saponin treatment. Comparing the flow cytometry and immunoassay results revealed that cell-associated cytokines are detectable by the flow cytometric method. In addition, the correlation between cytokine values obtained by the two different methods indicated that the results obtained by flow cytometry can be assessed semiquantitatively in detecting cell-associated cytokines.

The comparison between cell-associated IL-1 $\beta$ and TNF- $\alpha$ in the CTL subjects and the SAR patients suggested that the AMs of SAR patients have a greater capacity to produce TNF- $\alpha$ than the AMs of the CTL subjects, which is consistent with previous studies [17, 18]. In addition, our flow cytometric procedure revealed a qualitative difference in AM populations. All AMs possess equal capacity to produce IL- $1 \beta$ in response to LPS stimulation, both in the CTL subjects and SAR patients. In contrast, although all LPS-stimulated AMs had the same capacity to produce TNF- $\alpha$ in the CTL subjects, there seemed to be two heterogeneous AM subgroups with different capacities to produce TNF- $\alpha$ in the SAR patients. Cell-associated cytokines may be useful as a marker of unidentified AM subpopulations.

The flow cytometric method makes it possible to identify cytokine-producing cells without using cell-separating procedures, which are time-consuming and often

Table 3. - Percentage positive AMs in CTL subjects and SAR patients according to the results of flow cytometry

\begin{tabular}{lccccccc}
\hline & \multicolumn{2}{c}{ IL-1 $\beta(\%$ positive cells $)$} & & \multicolumn{3}{c}{ TNF- $\alpha(\%$ positive cells) } \\
\cline { 2 - 4 } \cline { 6 - 8 } Group & Uncultured & LPS(-) & LPS $(+)$ & & Uncultured & LPS $(-)$ & LPS $(+)$ \\
\hline CTL $(n=4)$ & $0.6 \pm 0.2$ & $1.4 \pm 0.6$ & $1.4 \pm 0.7$ & & 0 & 0 & $0.9 \pm 0.3$ \\
SAR $(n=5)$ & $2.9 \pm 1.5$ & $3.5 \pm 2.7$ & $6.2 \pm 4.3$ & & 0 & $0.1 \pm 0.0$ & $20.5 \pm 5.3^{*}$ \\
\hline
\end{tabular}

Values are presented as mean \pm sem. *: $\mathrm{p}<0.05$, as compared with CTL. For further definitions see legends to table 1 and 2 . 
reduce cell yields. As shown in figure 3, TNF- $\alpha$ levels were higher in the LPS(-) group than in the uncultured group, suggesting that TNF- $\alpha$ was actually induced by adhesion in the present study. Although immunohistochemical staining and in situ hybridization have been employed to avoid cell-separating procedures, these methods are less sensitive and less quantitative than the flow cytometric method [5]. Direct semiquantitative detection of cytokine proteins is another merit of this procedure. The degree of cytokine mRNA expression is not always correlated with the amount of cytokine protein produced. There are many regulatory mechanisms, in addition to transcriptional and post-transcriptional regulation, which could affect the final production of cytokines [9].

The flow cytometric method promises to be applicable to various future investigations. This procedure may be useful for studying membrane-bound and secreted forms of cytokines. While both cytokine forms may have been detected by the flow cytometric method using saponin treatment in this study, a membrane-bound form would be detected if the flow cytometric method were performed without saponin treatment [19]. In addition, by introducing two-colour analysis using a cell surface marker and a cytokine antibody, this method may make it possible to examine cytokine production by a selected population of bronchoalveolar lavage fluid cells. Subpopulations of monocytes with different tumour necrosis factor- $\alpha$ producing capacities have recently been reported [20]. Two-colour analysis may distinguish between the similar subpopulations of alveolar macrophages which were shown to exist in the present study.

Acknowledgements: The authors acknowledge the considerable help and guidance of T. Kawashiro (National Higashi-Saitama Hospital) and also thank Y. Miyazaki and S. Kaneko (Ortho Diagnostics Co., Tokyo, Japan) for their expert technical assistance in the flow cytometric analysis.

\section{References}

1. Elias JA, Freundlich B, Kern JA, Rosenbloom J. Cytokine networks in the regulation of inflammation and fibrosis in the lung. Chest 1990; 97: 1439-1445.

2. Kovacs EJ. Fibrogenic cytokines: the role of immune mediators in the development of scar tissue. Immunol Today 1991; 12: 17-23.

3. Thomas PD, Hunninghake GW. Current concepts of the pathogenesis of sarcoidosis. Am Rev Respir Dis 1987; 135: 747-760.

4. Hunninghake GW. Release of interleukin-1 by alveolar macrophages of patients with active pulmonary sarcoidosis. Am Rev Respir Dis 1984; 129: 569-572.

5. Lynch JP, Standiford TJ, Rolfe MW, Kunkel SL, Strieter
RM. Neutrophilic alveolitis in idiopathic pulmonary fibrosis. Am Rev Respir Dis 1992; 145: 1433-1439.

6. Car BD, Meloni F, Luisetti M, Semenzato G, GialdroniGrassi G, Walz A. Elevated IL-8 and MCP-1 in the bronchoalveolar lavage fluid of patients with idiopathic pulmonary fibrosis and pulmonary sarcoidosis. Am $J$ Respir Crit Care Med 1994; 149: 655-659.

7. Carré PC, Mortenson RL, King Jr TE, Noble PW, Sable CL, Riches DWH. Increased expression of the interleukin-8 gene by alveolar macrophages in idiopathic pulmonary fibrosis. J Clin Invest 1991; 88: 1802-1810.

8. Kasahara K, Strieter RM, Chensue SW, Standiford TJ, Kunkel SL. Mononuclear cell adherence induces neutrophil chemotactic factor/interleukin-8 gene expression. J Leukocyte Biol 1991; 50: 287-295.

9. Dinarello CA. Interleukin-1. In: Thomson AW, ed. The Cytokine Handbook. London, Academic Press, 1991; pp. 47-82.

10. DeCaestecker MP, Telfer BA, Hutchinson IV, Ballardie FW. The detection of intracytoplasmic interleukin-1 $\alpha$, interleukin- $1 \beta$ and tumor necrosis factor- $\alpha$ expression in human monocytes using two colour immunofluorescence flow cytometry. J Immunol Methods 1992; 154 11-20.

11. Jung T, Schauer U, Heusser C, Neumann C, Rieger C. Detection of intracellular cytokines by flow cytometry. J Immunol Methods 1993; 159: 197-207.

12. Sander B, Andersson J, Andersson U. Assessment of cytokines by immunofluorescence and the paraformaldehyde-saponin procedure. Immunol Rev 1991; 119: 65-93.

13. The BAL co-operative group steering committee. Bronchoalveolar lavage constituents in healthy individuals, idiopathic pulmonary fibrosis, and selected comparison groups. Am Rev Respir Dis 1990; 141 (Suppl.): 169-202.

14. Paulin-Levasseur M, Brown DL. Vimentin dynamics during the mitogenic stimulation of mouse splenic lymphocytes. Cell Motility Cytoskeleton 1987; 8: 227-237.

15. Munoz C, Misset B, Fitting C, Blériot JP, Cavaillon JC, Cavaillon JM. Dissociation between plasma and monocyte-associated cytokines during sepsis. Eur J Immunol 1991; 21: 2177-2184.

16. Pelham HRB. Multiple targets for brefeldin A. Cell 1991; 67: 449-451

17. Bachwich PR, Lynch JP, Larrick J, Spengler M, Kunkel SL. Tumor necrosis factor production by human sarcoid alveolar macrophages. Am J Pathol 1986; 125: 421-425.

18. Spatafora M, Merendino A, Chiappara G, et al. Lung compartmentalization of increased TNF releasing ability by mononuclear phagocytes in pulmonary sarcoidosis. Chest 1989; 96: 542-549.

19. Zola H, Flego L, Wong YT, Macardle PJ, Kenney JS. Direct demonstration of membrane IL- $1 \alpha$ on the surface of circulating B-lymphocytes and monocytes. J Immunol 1993; 150: 1755-1762.

20. Szabo G, Miller-Graziano CL, Wu JY, Takayama T, Kodys K. Differential tumor necrosis factor production by human monocyte subsets. J Leukocyte Biol 1990; 47: 206-216. 